\title{
Control strategy of a fuel-cell power module for electric forklift
}

\author{
Gojmir Radica ${ }^{a, *}$, Ivan Tolj ${ }^{a, * *}$, Dario Markota ${ }^{a}$, Mykhaylo V. Lototskyy ${ }^{b}$, \\ Sivakumar Pasupathi ${ }^{b}$, Volodymyr Yartys ${ }^{c}$ \\ a University of Split, Faculty of Electrical Engineering, Mechanical Engineering and Naval Architecture, Split, Croatia \\ ${ }^{\mathrm{b}}$ HySA Systems Competence Centre, South African Institute for Advanced Materials Chemistry (SAIAMC), \\ University of the Western Cape, Belluille, South Africa \\ ${ }^{c}$ Institute for Energy Technology, Kjeller, Norway
}

\section{H I G H L I G H T S}

- Lift truck simulation model with hybrid power pack is developed.

- PEMFC-Battery hybrid model for lift truck application was analyzed.

- Real lift truck load cycle was simulated.

- Balance of plant optimization and control strategy was done.

\section{A R T I C L E I N F O}

\section{Article history:}

Received 25 September 2020

Received in revised form

23 October 2020

Accepted 31 January 2021

Available online 20 February 2021

\section{Keywords:}

Hybrid forklift truck

PEMFC-battery power pack

Real load cycle simulation

Optimisation

Control strategy

\begin{abstract}
A B S T R A C T
Fuel cell-battery hybrid systems for the powertrain, which have the advantage of emissionfree power generation and adapt to material transport and emission reduction, are investigated. Based on the characteristics of the fuel cell system and the characteristics of the electric forklift truck powertrain system, this work defines the design principle of the control strategy to improve overall performance and economy. A simulation platform for fuel cell and electric vehicles has been established. The optimal performance of the fuel cell stack and the battery capacity were defined for the specific application. An energy control strategy was defined for different operating cycles and operating conditions. Model validation involved comparing simulation results with experimental data obtained during VDI60 test protocol. The main parameters that influence the forklift performance were defined and evaluated, such as energy loss, fuel cell operating conditions and different battery charging cycles. The optimal size of the fuel cell stack of $11 \mathrm{~kW}$ and the battery of 10 Ah was determined for the specific load profile with the proposed control strategy. The results obtained in this work forms the basis for an in-depth study of the energy management of fuel cell battery drive trains for forklift trucks.
\end{abstract}

๑ 2021 Hydrogen Energy Publications LLC. Published by Elsevier Ltd. All rights reserved.

\footnotetext{
* Corresponding author.

** Corresponding author.

E-mail addresses: goradica@fesb.hr (G. Radica), itolj@fesb.hr (I. Tolj). 


\section{Introduction}

Forklift trucks, which are mainly battery powered, are mainly used for material handling where strict requirements regarding environment, explosion and toxic restrictions apply, such as in the medical, mining and food industry. Fuel cell power packs are a superior alternative to industrial lead-acid batteries in electric forklifts and other material handling equipment. Fuel cells are safer, cleaner and more efficient than battery-powered forklift trucks. The fuel cell produces no harmful emissions and offers a solution without the cost of handling and storing toxic materials. The primary energy consumption and greenhouse gas emissions of electric vehicles in the vehicle life cycle are significantly higher than those of fuel cell powered vehicles, due to the high energy consumption and emissions associated with battery production [1].

Fuel cell hybrid energy systems (FCHVs) have the greatest potential for the final step in the transition of the industrial, earthmoving and transport sectors to the environmentally friendly powertrains, especially for heavier vehicles such as trucks and forklifts [2]. A comparison of the energy distribution between a fuel cell electric vehicle (FCEV) and a fuel cell hybrid electric vehicle (FCHEV) is carried out, with the FCHEV showing better results than the FCEV [3]. The main power source of the FCHEV is the fuel cell system (FCS), where battery is used to store energy. Using the battery as the energy storage system (ESS) for the FCHEV application instead of the powertrain only FCS, has the following advantages: i) ESS improves acceleration response by optimizing the operation of the fuel cell at high load and with energy gain during braking, ii) the energy storage system improves the hydrogen economy and iii) peak power demand of the powertrain can be achieved with energy from ESS and the fuel cell can be used for driving mode only. In fuel cell power modules, the innovation in energy storage technology is in the use of a metal hydride $(\mathrm{MH})$ hydrogen storage systems [4]. The main problem with the commercialisation of fuel cells is their durability. $5000 \mathrm{~h}$ is a minimum service life of the fuel cell unit to be competitive with the classic IC-drive train [5]. The main aging accelerator is the load dynamics [6]. Fuel cell degradation is caused by gas deficiency, dehydration of the membrane, flooding of the electrodes with porous media and load change intervals [7]. Keeping reactants relative humidity along the flow channels close to $100 \%$ increases fuel cell performance and its durability [8].

The service life of the fuel cell can be increased by controlling the load dynamics. The future of fuel cell electric vehicles (FCEV) depends on their cost and performance competitiveness in the automotive market. The sensitivity analysis suggests that hydrogen price and fuel cell system cost are the main uncertainties determining the cost competitiveness of FCEVs [9].

The low discharge level and low charge rate are the main reasons for the reduction in battery life, which depends on operating conditions [10]. Typically, battery life can last up to several thousand cycles.

In hybrid electric vehicles, the power management system uses the battery power as the controlled variable and the battery state of charge as the controllable state [11,12].
A large amount of research has been focused on developing different strategies for controlling the power and load of battery FC hybrid systems for automotive applications. Various techniques such as convex optimization and dynamic programming are used for an optimal energy management strategy [13]. Multi-target optimization and genetic algorithms are used in the developed power management strategy with the most important parameters such as battery charge, hydrogen consumption and acceleration behaviour [14]. These strategies are used for offline optimization and are not suitable for real-time ones. As an example, for real-time energy management, the PI (Proportional Integral) control [15], fuzzy logic [16] and predictive control [17] can be used. These studies deals with the energy management strategies of fuel cell-battery hybrid systems and emphasize the real-time and load problems. The main goal is to determine the relevant optimization functions. Real-time optimization is implemented at the economic level to identify the optimal reference trajectory in [18].

In fuel cell applications, the most commonly used energy management systems are: fuzzy logic and PI logic, decoupling of frequency and machine state, dynamic behaviour of the FC - battery vehicle during transient loads and the selection of the optimal of these techniques based on many criteria related to hydrogen consumption, overall system efficiency, state of charge and DC bus voltage stability [19].

This work deals with the use of proton exchange membrane fuel cell (PEMFC) battery hybrid power module system for a forklift application. PEMFC battery hybrid fuel cells are investigated for the load profile of a forklift truck according to VDI 60/VDI 2198 standard protocol. The fuel (energy) consumption data given on forklift datasheets is typically shown for VDI 60 standard cycle. During this cycle, according to VDI 2198 standard protocol, the truck is to drive for one hour in forward direction with nominal load-carrier/tow tractors, with maximum towed load or maximum load, one half hourwithout break. The duration of driving/lifting/dropping cycle is $\sim 1$ min (60 cycles per $1 \mathrm{~h}$ ) and the distance, L, between lifting/dropping points is $30 \mathrm{~m}$.

Based on the operating conditions an optimal energy management strategy is proposed. The strategy determines the operating point of each component of the system in order to maximize overall system efficiency and proposes a technique for an optimized system based on criteria such as: hydrogen consumption, overall efficiency, battery state of charge and DC bus voltage stability.

The main objective of this article is to determine the optimal fuel cell stack power and battery capacity under VDI60 load profile.

The main result of the presented study is a novel control strategy for optimizing the PEM FC battery hybrid system under the real environmental conditions.

\section{Descriptions of the fuel cell - battery powered lift truck}

The system was built around the 3-ton STILL RX60-30L electric forklift truck and then converted to a fuel cell battery power supply with metal hydride storage extension tank [20]. In 
industrial trucks, PEMFCs are a better alternative to lead-acid batteries, mainly because no time is needed for replacement and because the PEMFC can always supply the truck with full power throughout the shift, even at low ambient temperatures such as $-30^{\circ} \mathrm{C}$. With PEMFC, the truck always operates at top speeds, regardless of how much fuel is left in the tank. For this study, a forklift truck is equipped with a $80 \mathrm{~V}$ lead-acid battery pack with a capacity of $25 \mathrm{Ah}$ and afterwards with GenDrive 80 VDC PEMFC power module (Plug Power). The metal hydride $(\mathrm{MH})$ hydrogen storage extension tank is accomodated [20].

The schematic of the PEMFC power module and $\mathrm{MH}$ hydrogen storage extension tank is presented in Fig. 1.

The power consumption by the components of the system Balance of Plant (BoP) is presented in Table 1 [20].

\section{Theoretical background basis of fuel cell}

The voltage of the fuel cell electro-chemical model is calculated as:
Table 1 - Power consumption by BoP components of the FC power module with MH extension tank [20].

Component

Contribution in the power consumption [W]

Power module electronics $\quad 143.6$

Other BoP components of the $\quad 1058.8$

power module providing

FC stack operation

MH thermal management system 313.8

TOTAL

1516.2

$U_{\text {cell }}=U_{O C}-\eta_{0}-j_{0} R$

where the three terms on the right-hand side of the equation are the ideal open circuit voltage, the cathode voltage loss and ohmic voltage loss of the fuel cell.

The ohmic loss is defined as:

$j_{0} R=\frac{I_{\text {stack }}}{A_{\text {area }} R}$

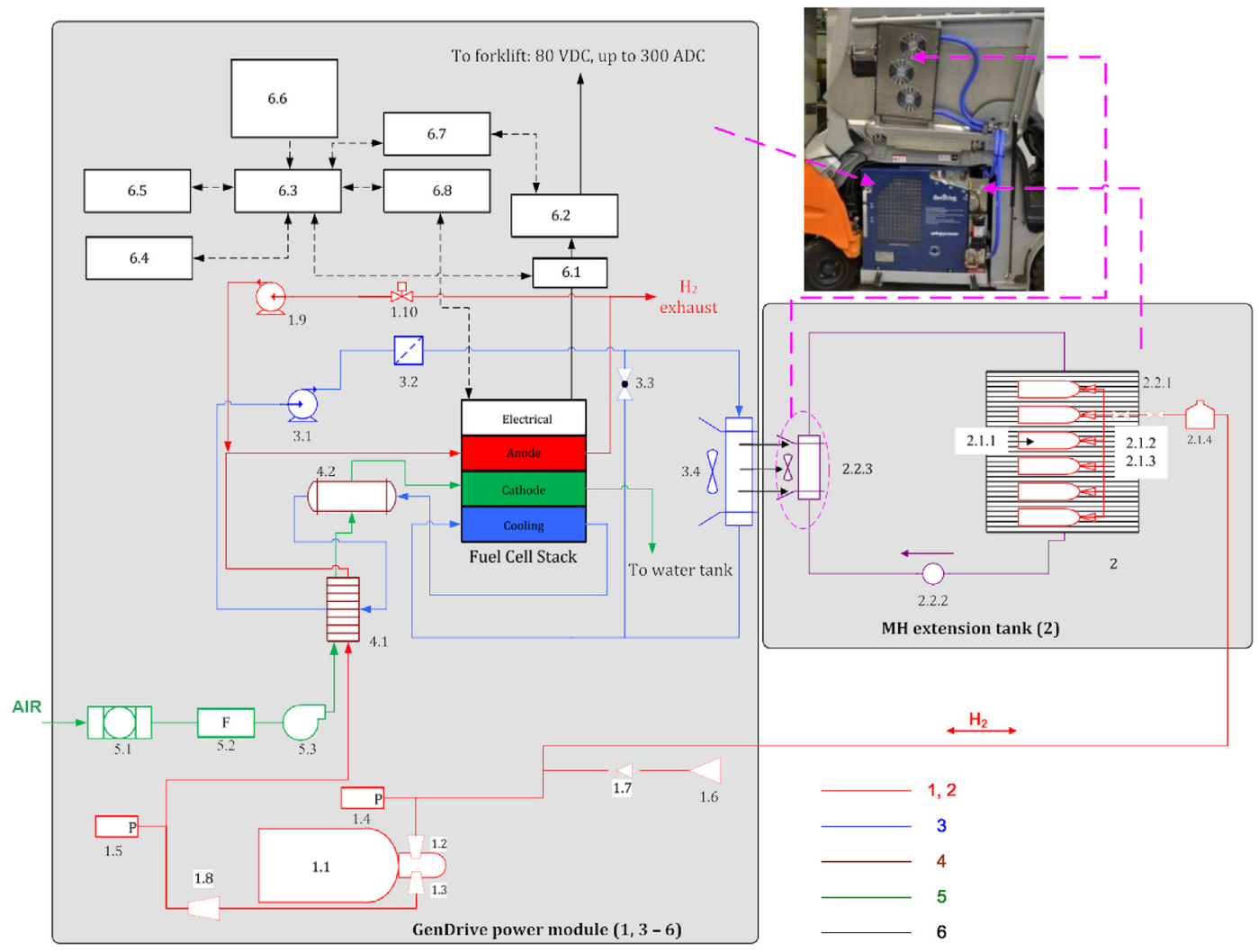

Fig. 1 - Simplified schematic of the PEM FC power module system [20]: 1 - hydrogen storage and supply subsystem: 1.1 gas cylinder, 1.2, 1.3 - adapters, 1.4, 1.5 - pressure sensors, 1.6 - refuelling receptacle, 1.7 - check valve, 1.8 - reducer, 1.9 recirculation pump, 1.10 - purge valve. 2 - MH extension tank: 2.1 - hydrogen subsystem: 2.1.1 - MH containers, 2.1.2, 2.1.3 - shut-off valves, 2.1.4 - gas filter; 2.2 - thermal management subsystem: 2.2.1 - water tank, 2.2.2 - circulation pump, 2.2.3 - radiator. 3 - FC stack cooling subsystem: 3.1 - coolant pump, 3.2 - DI filter, 3.3 - bypass valve, 3.4 - radiator. 4 fuel/oxidant conditioning: 4.1 - reactants conditioner, 4.2 - humidifier assembly. 5 - air supply subsystem: 5.1 - filter, 5.2 - flow meter, 5.3 - compressor. 6 - electrical components: 6.1 - contactor, 6.2 - Li-ion battery, 6.3 - system master controller, 6.4 - compressor motor controller, 6.5 - cell voltage monitor, 6.6 - BoP sensors (H2, tilt, coolant temperature, oxidant and fuel temperatures), 6.7 - battery sensors (voltage, current, SoC), 6.8 - stack sensors (voltage, current, temperature). 
where $j_{0}$ and $I_{\text {stack }}, A_{\text {area }}$ and $R$ are the stack current density, the stack current, the active area of the fuel cell, and the ohmic resistance of the fuel cell multiplied by the fuel cell area. The stack current of the fuel cell is the current demanded from the electrical network plus the crossover current of the fuel cell.

The cathode loss is defined as:

$\eta_{0}=a c t+t_{C C L}+t_{G D L}$

where act is the voltage drop caused by the activation loss, $t_{\mathrm{CCL}}$ is the voltage loss caused by the transport loss of oxygen in the CCL, $t_{\text {GDL }}$ is the voltage drop caused by the transport loss of oxygen in the GDL. The activation loss is defined as:

$a c t=b * \arcsin h\left(\frac{\left(\frac{j_{0}^{2}}{j_{a}}\right)}{2 \frac{c_{h}}{C_{\text {ref }}}\left(1-\exp \left(\frac{-j_{0}}{2 j *}\right)\right)}\right)$

where $b$ is the Tafel slope, $c_{h}$ is the oxygen concentration at the cathode channel, and $c_{r e f}$ is the oxygen concentration at the channel inlet.

The gas concentration at the cathode is calculated by using the molar flow of the gas defined as:

$n_{\mathrm{O}_{2}}(x)=\frac{I_{\text {stack }}}{F} \frac{S-x}{4}$

$n_{\mathrm{N}_{2}}(\mathrm{x})=n_{\mathrm{O}_{2}}(0) \frac{1.0-\mathrm{V}_{\mathrm{O}_{2}}}{\mathrm{~V}_{\mathrm{O}_{2}}}$

$n_{\mathrm{H}_{2} \mathrm{O}}(x)=\frac{I_{\text {stack }}}{F} \frac{1}{2} x$

and

$n_{\mathrm{O}_{2}, \mathrm{~N}_{2}, \mathrm{H}_{2} \mathrm{O}}(\mathrm{x})=n_{\mathrm{O}_{2}}+n_{\mathrm{N}_{2}}+n_{\mathrm{H}_{2} \mathrm{O}}$

where $F, S$, and $V_{\mathrm{O} 2}$ are Faraday constant, oxygen stoichiometric ratio, oxygen concentration in the air, and the variable $x$ describes the air path from the cathode inlet $(x=0)$ to the cathode outlet $(x=1)$. The gas concentration is calculated by:

$C_{s p}(x)=\frac{n_{s p}(x)}{n_{\mathrm{O}_{2}, \mathrm{~N}_{2}, \mathrm{H}_{2} \mathrm{O}}(\mathrm{x})} \frac{1}{V_{m}} \frac{\mathrm{T}_{\text {norm }}}{\mathrm{T}_{\text {cell }}} \frac{\mathrm{P}_{\text {cell }}}{\mathrm{P}_{\text {norm }}}$

where $C_{\mathrm{sp}}(\mathrm{x}), n_{\mathrm{sp}}(\mathrm{x}), \mathrm{V}_{\mathrm{m}}, \mathrm{T}_{\text {norm }}, P_{\text {norm }}, \mathrm{T}_{\text {cell }}$, and $P_{\text {cell }}$ are the concentration of a species, the molar flow of a species, the molar volume of an ideal gas at $T_{\text {norm }}=273.15 \mathrm{~K}$ and $P_{\text {norm }}$ $=1 \mathrm{bar}$, the fuel cell temperature and the cathode gas pressure, respectively. In the model, $C_{s p}(x)$ is the concentration of a species at the cathode.

In addition, $j_{\mathrm{a}}$ and $j_{*}$ in the equation above are defined as:

$j_{a}=\sqrt{2 i_{*} S_{t} b}$

where $i_{*}$ and $S_{t}$ are the volumetric exchange current density and the CCL proton conductivity, and:

$j_{*}=\frac{S_{t} b}{l_{t}}$

where $l_{t}$ is the thickness of the CCL.

The transport loss in the CCL is:
$t_{C C L}=\frac{\frac{S_{t} b^{2}}{4 F D c_{h}}\left(\frac{j_{0}}{j_{*}}-\ln \left(1+\frac{j_{0}^{2}}{j_{*}^{2} B^{2}}\right)\right)}{1-\frac{j_{0}}{j_{\text {lim }}^{*} \frac{c_{h}}{c_{\text {ref }}}}}$

where $D$ is the oxygen diffusion coefficient, and $F$ is the Faraday constant in the CCL; and ${ }^{*}{ }^{*} \lim$ and $B$ are defined as:

$j_{\text {lim }}^{*}=\frac{4 F D_{b} c_{\text {ref }}}{l_{b}}$

where $l_{b}$ is the GDL thickness and $D_{b}$ is the oxygen diffusion coefficient in the GDL, and

$B=2 \arctan \left(\frac{j_{0}}{2 \arctan \left(\frac{j_{0}}{2 \arctan \left(\frac{j_{0}}{2 \arctan \frac{j_{0}}{\sqrt{2 j_{0}}}}\right)}\right)}\right)$

The transport loss in the GDL is:

$t_{G D L}=-b \ln \left(1-\frac{j_{0}}{j_{\text {lim }}^{*} \frac{c_{h}}{c_{\text {ref }}}}\right)$

The voltage of the stack is:

$U_{\text {stack }}=U_{\text {cell }} * n_{\text {cells }}$

where $n_{\text {cells }}$ is the number of cells in the stack.

\section{Stoichiometric ratio}

The mass flow of the reacted hydrogen and oxygen can be calculated by:

$m_{\text {reacted }, \mathrm{H}_{2}}=\frac{\mathrm{I}_{\text {stack }} * n_{\text {cells }}}{4 * \mathrm{~F}} * \mathrm{M}\left(\mathrm{H}_{2}\right)$

and

$m_{\text {reacted, } \mathrm{O}_{2}}=\frac{I_{\text {stack }} * n_{\text {cells }}}{4 * \mathrm{~F}} \mathrm{M}\left(\mathrm{O}_{2}\right)$

where $\mathrm{M}\left(\mathrm{H}_{2}\right)$ and $\mathrm{M}\left(\mathrm{O}_{2}\right)$ are the molar masses of hydrogen and oxygen. Using the stoichiometric ratio, the mass flow of total amount of hydrogen and oxygen fed to the fuel cell is equal to:

$m_{\text {flow, } \mathrm{H}_{2}}=m_{\text {reacted, } \mathrm{H}_{2}} * S R_{\mathrm{H}_{2}}$

and

$m_{\text {flow }, \mathrm{O}_{2}}=m_{\text {reacted }, \mathrm{O}_{2}} * \mathrm{SR}_{\mathrm{O}_{2}}$

The mass flow of the demanded air fed to the cathode of the fuel cell is equal to: 
$m_{\text {flow,air }}=\frac{I_{\text {stack }} * n_{\text {cells }} * M(\text { Air })}{4 * F * O_{2} \text { (Air) }}$

where $\mathrm{M}$ (Air) and $\mathrm{O}_{2}$ (Air) are the average molar masses of the air and the oxygen in the air, respectively.

\section{Compressor}

In the compressor model embedded in the fuel cell system, the outlet gas pressure is calculated as:

$p_{\text {out }}=p_{\text {in }} * \Pi$

where the two terms on the right-hand side of the equation are the inlet gas pressure of the compressor and the pressure ratio, respectively. The outlet gas temperature is:

$\mathrm{T}_{\text {out }}=\mathrm{T}_{\text {in }} * \Pi^{\frac{k_{\text {gas }}-1.0}{k_{\text {gas }}}}$

where $T_{\text {in }}$ and $k_{\text {gas }}$ are the inlet gas temperature and the heat capacity ratio at a constant pressure to the heat capacity at a constant volume. The power consumption of the compressor is expressed as:

$P_{\text {compressor }}=m_{\text {flow,in }} * \frac{1}{n_{s, C}} * c_{p} * T_{\text {in }} *\left[\Pi^{\frac{k-1}{k}}-1\right]$

where $m_{\text {flow,in }}, n_{\mathrm{s}, \mathrm{C}}$ and $c_{p}$ are the mass flow of the compressor inlet, compressor isentropic efficiency and specific heat mean value at the constant pressure between the compressor inlet and outlet, respectively. When the compressor operates at idle speed, its inlet mass flow is equal to its idle mass flow. Otherwise, when higher gas pressure is required from the fuel cell stack, its inlet mass flow is:

$m_{\text {flow,in }}=m_{\text {flow, air }}$

\section{Power}

The fuel cell power is defined as:

$P_{\text {cell }}=U_{\text {cell }} * I_{\text {stack }}$

and the fuel cell power loss is:

$P_{\text {loss }, \text { cell }}=\left(U_{o c}-U_{\text {cell }}\right) * I$

The corresponding efficiency of the fuel cell is:

$\eta_{\text {cell }}=\left(\frac{U_{o c}-U_{\text {cell }}}{U_{o c}}\right)$

The compressor power can be fed into the electric system with the compressor current:

$I_{\text {compresor }}=\frac{P_{\text {compresor }}}{U_{\text {compresor }}}$

\section{Model of a fuel cell hybrid power pack}

A PEM fuel cell battery power supply model for forklift trucks is shown in Fig. 2. Model was developed by commercial AVL CRUISETM M software. AVL CRUISETM $\mathrm{M}$ is a multi-disciplinary vehicle system simulation tool. It can be used for powertrain concept analysis, sub-system design and virtual component integration. Alternatively, it can be used in HiL (Hardware-inthe-Loop) environments for control function development and in testbed environments.

The power is controlled by a bidirectional DC/DC converter. It operates at different voltage levels and controls the charging and discharging of the battery pack. The battery is directly coupled to the DC bus and the PEM fuel cell is connected to the bus with a unidirectional DC/DC converter. In this way the output power of the fuel cell is controlled.

The presented forklift power supply system uses the same DC bus voltage as the battery voltage, and direct bus voltage regulation is avoided. Due to several advantages, this control of the fuel cell-battery hybrid unit is beneficial for the forklift application. The monitor function is used for monitoring selected set of results and to control values of component input values during the simulation such as: current, power or battery state of charge. The map component serves as characteristics inputs component, which is in this case power according to VDI 60 load profile.

The fuel cell model is based on analytical electrochemical equations derived from the polarization curve of the cathode side of the PEMFC. The approximate solution of the equations considers the oxygen and proton transport losses in the CCL and the oxygen transport losses in the GDL for different temperature, relative humidity, and gas pressure on the cathode side. The model can be used to evaluate electrical properties such as voltage, power, power loss, fuel cell efficiency and gas properties such as the total amount of oxygen and hydrogen consumed. Also, a simple compressor model can be activated in addition to the fuel cell so that the power consumption of the compressor, which has a significant influence on the operating efficiency of the fuel cell system, can be taken into account. Fuel cell characteristics of the power module are presented in Table 2 . The battery model is based on an electrical equivalent circuit diagram and can predict the voltage response to a current at a certain state of charge (SoC) and temperature.

The basic model consists of a controlled voltage source and an ohmic resistance, which is used to describe the instantaneous voltage response to a current input. In an advanced model, one or more RC networks could be added to the electrical circuit to predict the transient voltage response to a dynamic current load. The battery characteristics are listed in Table 3. The battery voltage depends on the battery state of charge. During discharge of the battery, both individual cells and the total battery voltage drops. It is therefore necessary to determine the limits of the battery state of charge not only because of the voltage drop, but also to extend battery lifetime. The nominal capacity of the battery is $25 \mathrm{Ah}$, while the minimum and maximum voltages are 3 and $3.9 \mathrm{~V}$.

The battery charge status indicates the remaining battery capacity in relation to its nominal capacity. The state of charge (SoC) is an important parameter in battery management system. Its accurate adjustment is necessary to maintain an acceptable battery life and safe use of the battery pack. The state of charge is implemented according to the diagram in Fig. 3. 


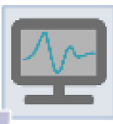

Monitor 1

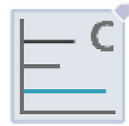

Fuel Cell Desired Current

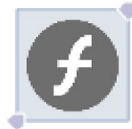

Function 1

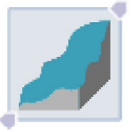

Map 1

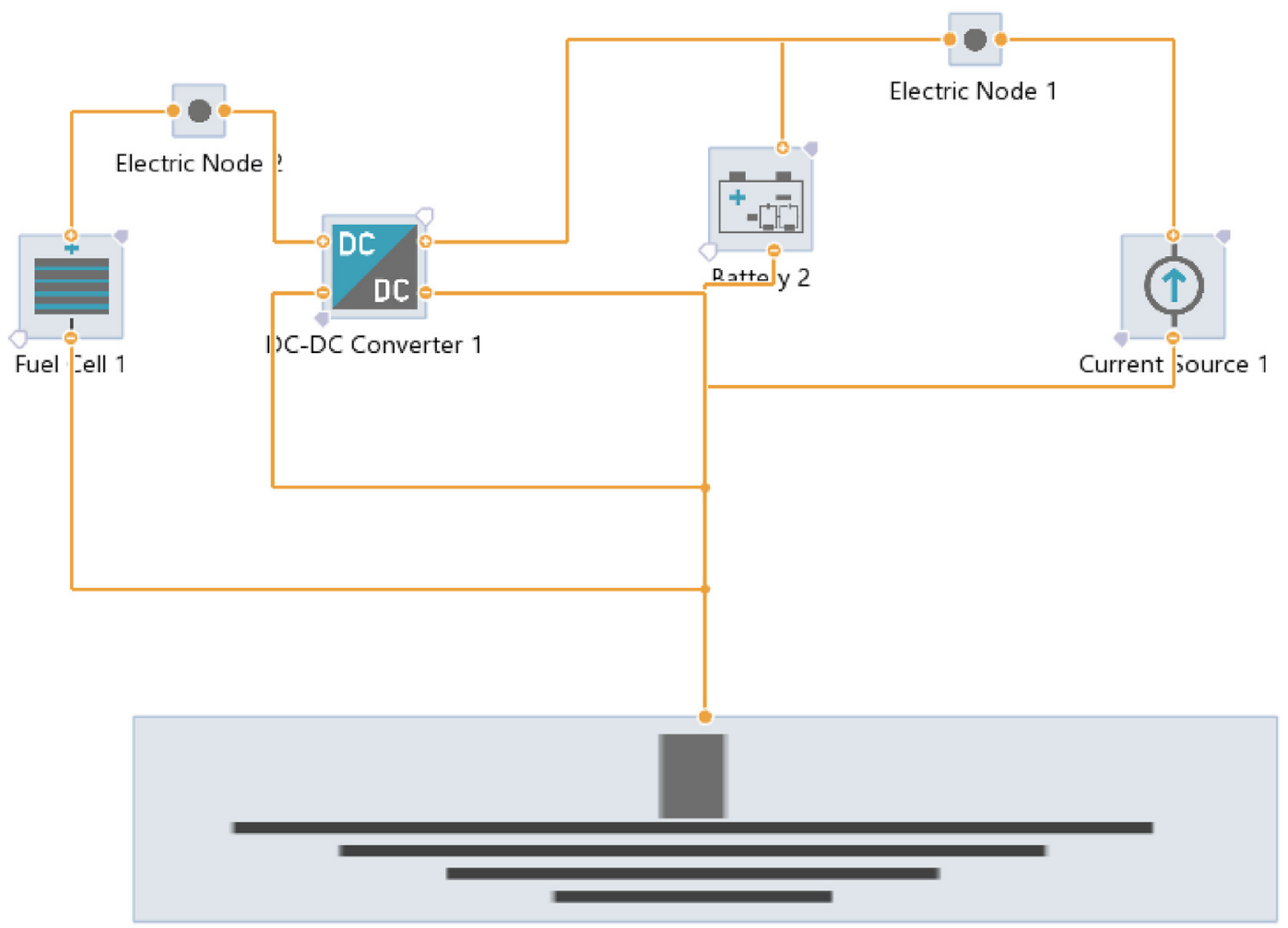

Ground 1

Fig. 2 - PEM fuel cell-battery power pack model.

Table 2 - Power module fuel cell stack characteristics.

Number of cells in a stack

Fuel cell stack active area

Ideal open circuit voltage

Tafel slope

Catalyst layer thickness

GDL thickness

Maximum current

Oxygen concentration

Cathode inlet gas pressure

Relative humidity
75

$370 \mathrm{~cm}^{2}$

$1,23 \mathrm{~V}$

$0,03 \mathrm{~V}$

$0,001 \mathrm{~cm}$

$0,02 \mathrm{~cm}$

$1000 \mathrm{~A}$

$21 \%$

2 bar

$70 \%$

\section{Table 3 - Power module battery properties.}

Number of cells per row

Number of cell-rows

Minimum voltage

Maximum voltage

Contact resistance

Initial state of charge 2,294444e-04 mOhm $70 \%$
$15 \mathrm{~kW}$ PEMFC power module with integrated $\mathrm{MH} \mathrm{H}_{2}$ storage tank for a 3-tonne electric forklift has been tested according to VDI60 standard protocol (Fig. 4).

VDI60 test results are presented in Fig. 5. Ambient temperature during the tests was $26.5^{\circ} \mathrm{C}$. Load energy consumption 60 VDI combustion cycles/hour was $9.564 \mathrm{kWh} / \mathrm{h}$.

Load power captured during the VDI60 test was implemented into the developed AVL CRUISETM $\mathrm{M}$ model and simulation was performed. To validate model, hydrogen consumption measured during the VDI60 test was compared with hydrogen consumption obtained from the simulation results. Hydrogen consumption of $690 \mathrm{NL} \mathrm{kWh}^{-1}$ was found to be in a good agreement with measured hydrogen consumption during the VDI60 test. This hydrogen consumption allows uninterrupted heavy-duty operation for $3 \mathrm{~h}$ and 6 min which is only $22.5 \%$ shorter than the maximum duration of similar operation of the forklift in the original battery powering mode. Peak power during VDI60 cycle was $\sim 30 \mathrm{~kW}$.

\section{Results and discussion}

The AVL CRUISETM M software was used to successfully implement the hybrid functionalities of the forklift truck. Before running the simulation, it was necessary to determine 


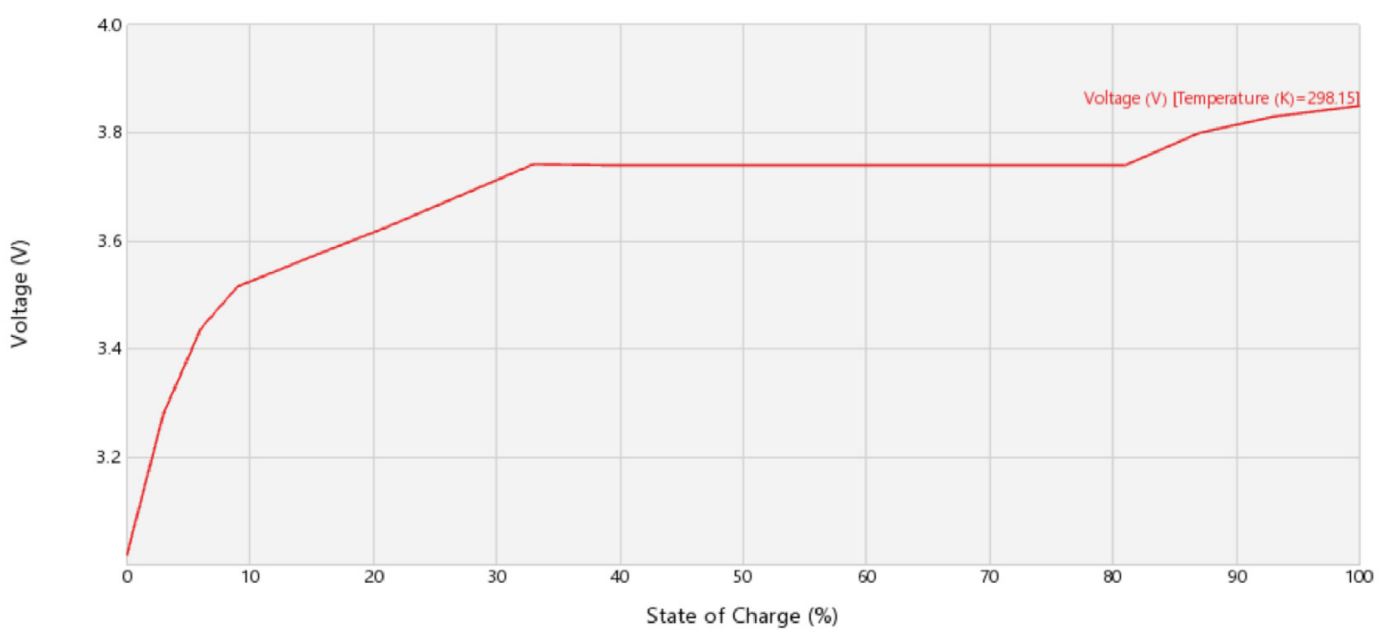

Fig. 3 - Battery state of charge (SoC).
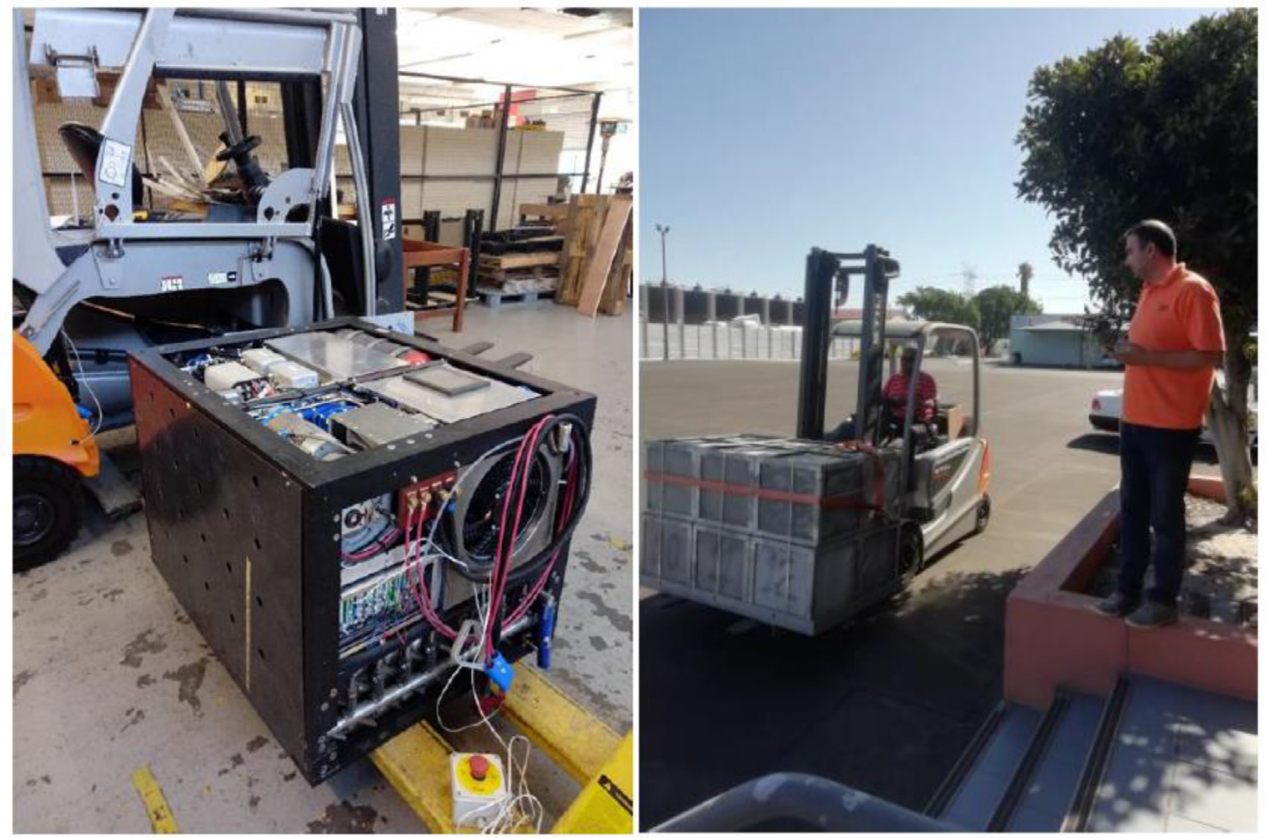

Fig. 4 - Left - shows $15 \mathrm{~kW}$ - PEMFC power module before installation in STILL RX60-30 forklift. Right - Prof. I. Tolj (FESB, Split) supervises VDI-60 test of the forklift (Cape Town, South Africa).

the driving conditions under which the vehicle will be exposed and to select the appropriate driving cycle according to these conditions. Driving cycles describes the actual loads that can occur during the drive. Fig. 6 shows the most important characteristics for default values.

The number of cells in a stack is 75 , active fuel cell stack area $370 \mathrm{~cm}^{2}$, battery voltage is $75 \mathrm{~V}$, nominal battery capacity is $25 \mathrm{Ah}$ and fuel cell stack current is $125 \mathrm{~A}$. With this current value the fuel cell power is maintained at $11 \mathrm{~kW}$. It can be seen that SoC of the battery remains at a reasonable levels. The fuel cell stack kicks in when the state of charge drops below 50\% and the switches off once when the state of charge reaches $82 \%$. During the entire simulation (3600 s) fuel cell stack output current was stable and fuel cell output power gradually followed the load power demand thus avoiding the effects of abrupt load changes on the fuel cell. The battery pack is charged and discharged according to the load power demands. The mass flow of the reacted hydrogen was between $0.13 \mathrm{~g} / \mathrm{s}$ and $0.15 \mathrm{~g} / \mathrm{s}$ (corresponds to $10-15 \mathrm{NL} / \mathrm{min}$ per $1 \mathrm{~kW}$ ) as shown in Fig. 7. Total mass of the reacted hydrogen was $0.45 \mathrm{~kg}$.

For the next simulation case the same parameters were used, except for the battery capacity (10 Ah instead of $25 \mathrm{Ah}$ ). Results are presented in Fig. 8.

The output power of the fuel cell stack remains unchanged (11 kW), but the battery state of charge changed. When the battery state of charge drops to $20 \%$ the fuel cell kicks in and switches off once when the battery SoC reaches $100 \%$. The 


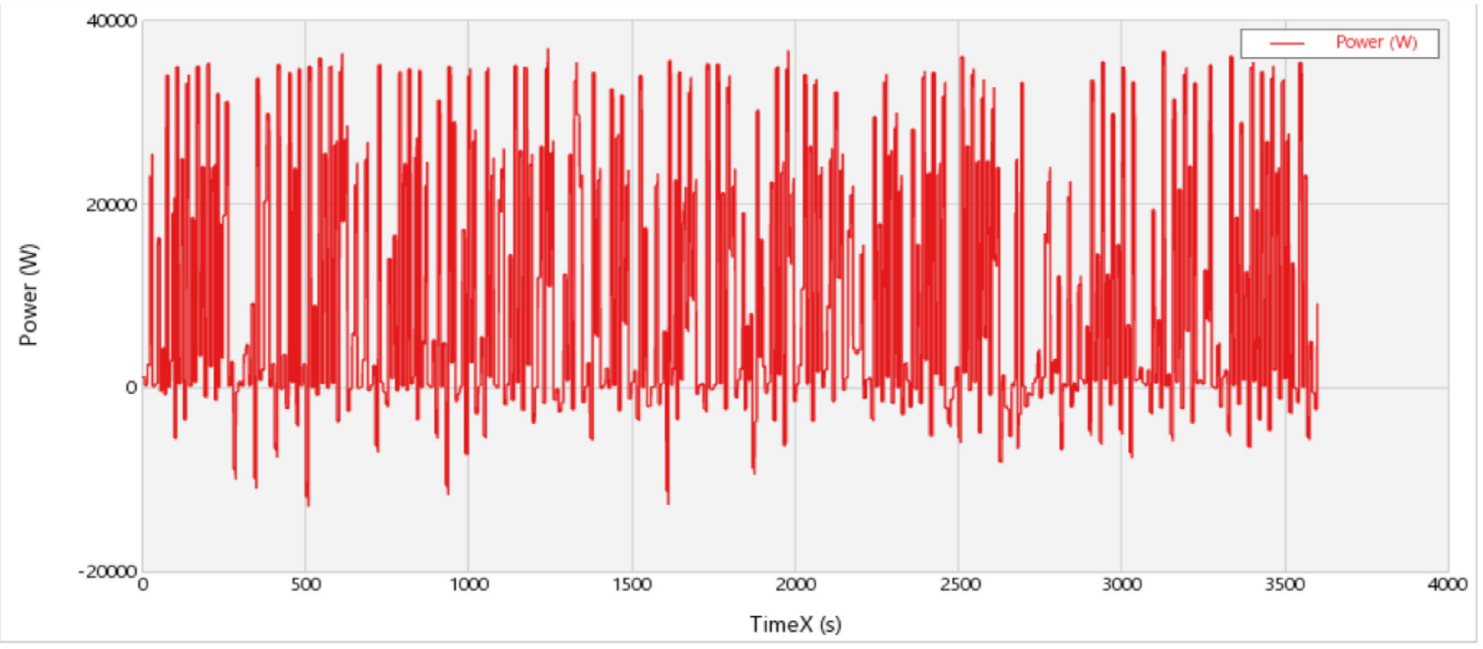

Fig. 5 - Load power during VDI60 test.

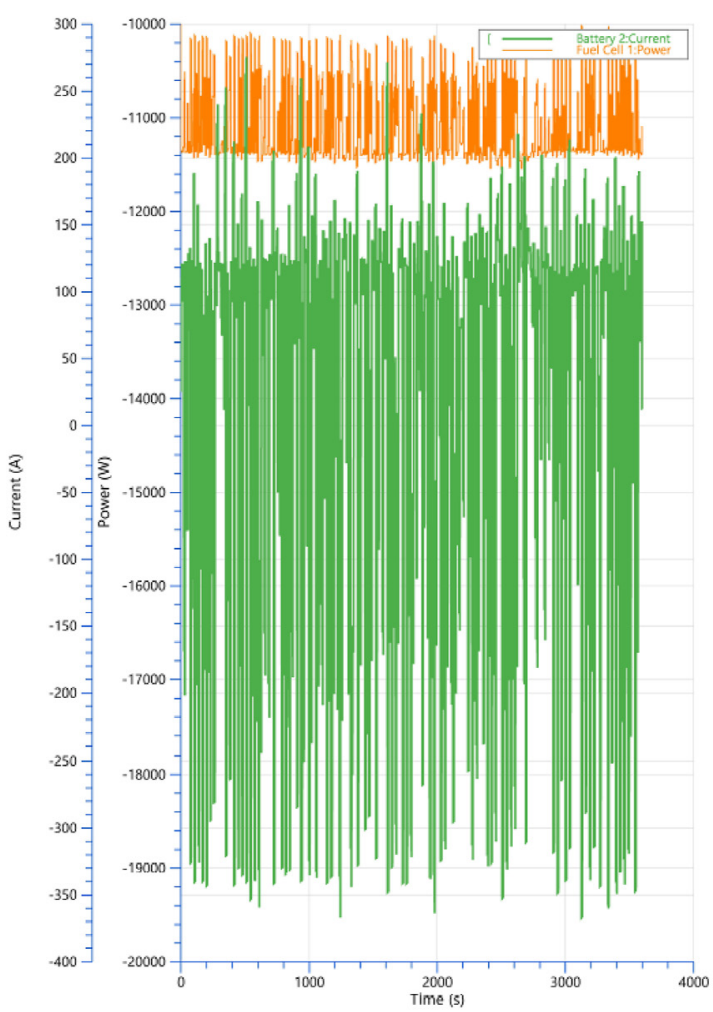

A)

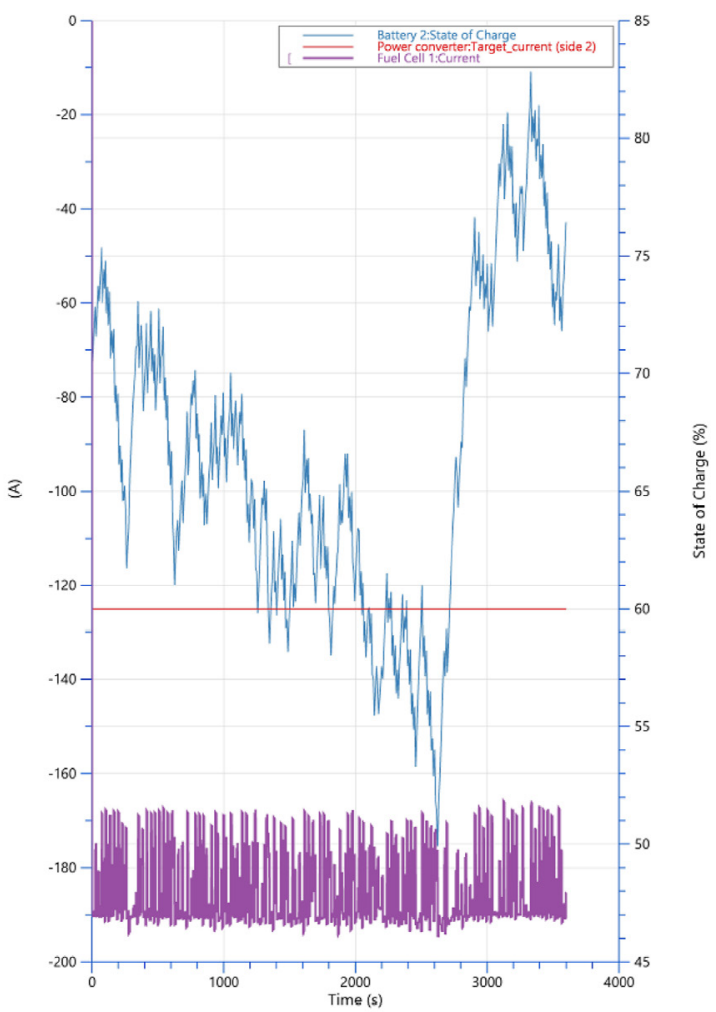

B)

Fig. 6 - Simulation 1 - Battery capacity $25 \mathrm{Ah}$, fuel cell stack power $11 \mathrm{~kW}$; battery current and fuel cell stack power (A); battery SoC and fuel cell stack current (B).

reacted hydrogen mass during the simulation was $0.51 \mathrm{~kg}$. The mass flow of reacted hydrogen was between $0.135 \mathrm{~g} / \mathrm{s}$ and $0.155 \mathrm{~g} / \mathrm{s}$. Optimal results were achieved with a battery capacity of $10 \mathrm{Ah}$.

Main simulation results are summarized in the Table 4. Optimal results (battery SoC between 25 and 100\%) are presented in the last column. SoC between 25 and $100 \%$ gives stable operation and longer battery life.

\section{Conclusions}

In this paper the performance of PEM fuel cell battery powered module for forklift truck is investigated. An efficient optimal energy control strategy is proposed and elaborated. The model of PEM fuel cell powered forklift truck was developed in AVL CRUISETM $^{\mathrm{TM}}$ software and the VDI60 load profile captured 


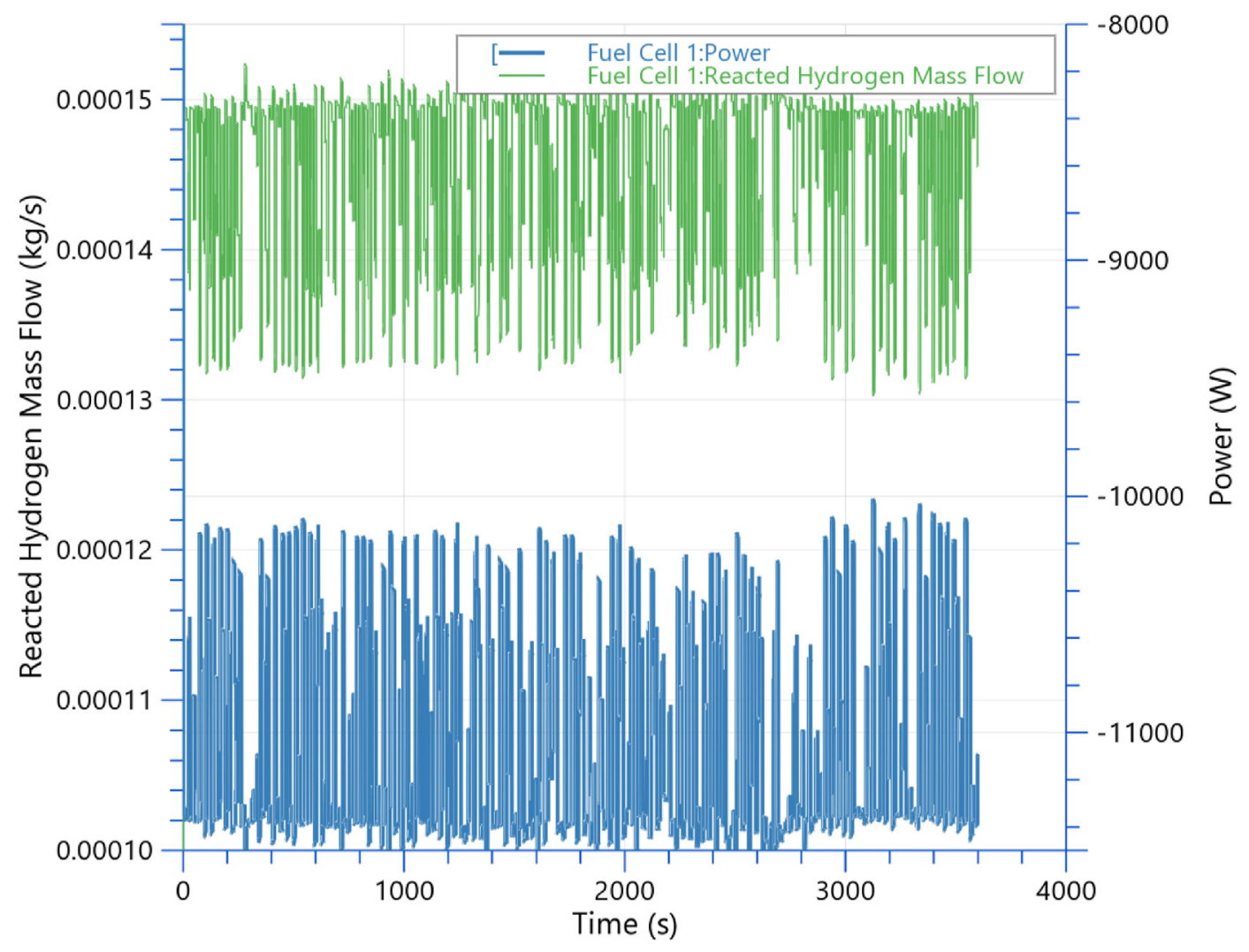

Fig. 7 - Power and Reacted Hydrogen Mass Flow during Load Cycle.

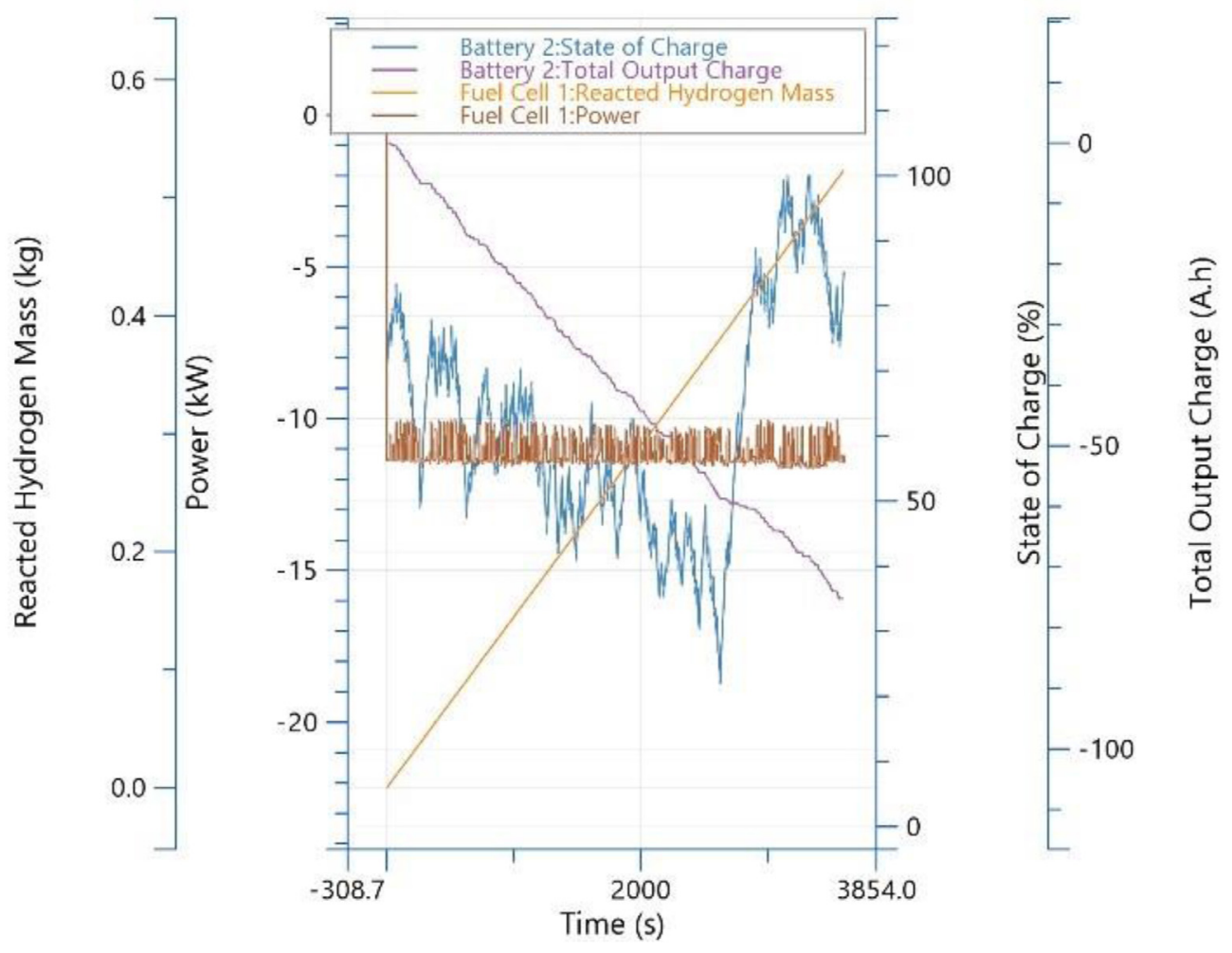

Fig. 8 - Simulation 2 - Battery capacity $10 \mathrm{Ah}$, fuel cell power $11 \mathrm{~kW}$. 
Table 4 - Main simulation results.

FC75_370 $\mathrm{cm}^{2}$-Bat75 V
25 Ah-Target Current

25 Ah-Target Current - 125115 A Power modul-v.9-r2 A Power modul-v.9-r1
50 Ah-Target Current $-115 \mathrm{~A}$ Power modul-v.9-r3

FC75_370 $\mathrm{cm}^{2}$-Bat75 V 10 Ah-Target Current 125 A Power modul-v.9-r6

\begin{tabular}{lll}
\hline FCP $(\mathrm{kW})$ & $11(10,-12)$, & $10(9.5-10.5)$ \\
BPe $(\mathrm{kW})$ & $-22,-12$ & $-25,-13$ \\
SOC & $52-82$ & $22-48$ \\
TOC (Ah) & $40(1500 \mathrm{~s})$ & $40(1450 \mathrm{~s})$ \\
RHM (kg) & 0.45 & 0.41 \\
RHMF (g/s) & $0.13-0.15$ & $0.124-0.136$ \\
TOE (MJ) & 20.5 & 22 \\
\hline
\end{tabular}

$\begin{array}{ll}10 & 11 \\ -25,-13, & -25,-13 \\ 45-58 & 25-100 \\ 80(3600 \mathrm{~s}) & 72(3600) \\ 0.52 & 0.52 \\ 0.12-0.136 & 0.132-0.15 \\ 22 & 22\end{array}$

during forklift test was implemented. Model was validated by comparing hydrogen consumption obtained from simulation results with consumption measured during VDI60 test. Hydrogen consumption of $690 \mathrm{NL} \mathrm{kWh}^{-1}$ was found to be in a good agreement with measured hydrogen consumption during the VDI60 test. This allows uninterrupted heavy-duty operation for $3 \mathrm{~h}$ and 6 min which is only $22.5 \%$ shorter than the maximum duration of similar operation of the forklift in the original battery powering mode.

The optimal battery size for the considered 3-ton electric forklift was found to be 10 Ah with the fuel cell stack power of $11 \mathrm{~kW}$. The proposed novel control strategy determines the operating point of each component of the system to maximize system efficiency for different operating cycles and working conditions. For future work, this control strategy will be used to optimize PEM FC battery hybrid system in different environmental and working conditions.

\section{Declaration of competing interest}

The authors declare that they have no known competing financial interests or personal relationships that could have appeared to influence the work reported in this paper.

\section{Acknowledgment}

This work is supported by the European Union's Horizon 2020 research and innovation programme under the Marie Skłodowska-Curie grant agreement No. 778307 (Call: H2020-MSCARISE-2017 - Marie Skłodowska-Curie Research and Innovation Staff Exchange).

The South African partners acknowledge financial support of the Department of Science and Innovation of South Africa within the Hydrogen South Africa (HySA) Program; Key Programme KP6 "Metal Hydride Materials and Technologies".

\section{Symbols}

BoP Balance of Plant

CCL cathode diffusion layer

FCP Fuel cell power

GDL gas diffusion layer

I cell current of the electro-chemical fuel cell model $\eta_{\text {norm }} \quad$ corresponding fuel cell efficiency

$P_{\text {compressor }}$ compressor power consumption

$P_{\text {cell }} \quad$ power of the fuel cell

RHM Reacted Hydrogen Mass

RHMF Reacted Hydrogen Mass Flow

TOC Total output charge

TOE Total output energy

Tnorm temperature of the fuel cell

Tout outlet gas temperature

Tin inlet gas temperature

Ucell voltage of the electro-chemical model of the fuel cell

UOC ideal open circuit voltage

Ustack voltage of the stack

\section{R E F E R E N C E S}

[1] Yang Z, et al. Life cycle assessment of fuel cell, electric and internal combustion engine vehicles under different fuel scenarios and driving mileages in China. Energy 2020;198:117365.

[2] Deign J. Hydrogen mobility. https://www.greentechmedia. com/articles/read/hydrogen-mobility-coming-soon-to-abus-or-truck-near-you; October 2020.

[3] Hüseyin B, et al. Energy distribution analyses of an additional traction battery on hydrogen fuel cell hybrid electric vehicle. Int J Hydrogen Energy 2020;45:26344-56.

[4] Lototoskyy MV, et al. "Distributed hybrid" MH-CGH2 system for hydrogen storage and its supply to LT PEMFC power modules. J Alloys Compd 2015;645:S329-33.

[5] Analyses and projections, US Energy information. https:// www.energy.gov/energy-economy/prices-trend; April 2020.

[6] Pei P, et al. A quick evaluating method for automotive fuel cell lifetime. Int J Hydrogen Energy 2008;33:3829-36.

[7] Pei P, et al. Main factors affecting the lifetime of Proton Exchange Membrane fuel cells in vehicle applications: a review. Appl Energy 2014;125:60-75.

[8] Özden E, et al. Designing heat exchanger with spatially variable surface area for passive cooling of PEM fuel cell. Appl Therm Eng 2013;51:1339-44.

[9] Chena Y, et al. Model-based techno-economic evaluation of fuel cell vehicles considering technology uncertainties. Transport Res Transport Environ 2019;74:234-44.

[10] Ecker M, et al. Calendar and cycle life study of Li(NiMnCo)O2based 18650 lithium-ion batteries. J Power Sources 2014;248:839-51.

[11] Wang X, et al. Comparative study on different energy management strategies for plug-in hybrid electric vehicles. Energies 2013;6:5656-75.
$P_{\text {loss, cell }}$ power loss of the fuel cell 
[12] Andreasen SJ, et al. Test of hybrid power system for electrical vehicles using a lithium-ion battery pack and a reformed methanol fuel cell range extender. Int J Hydrogen Energy 2014;39:1856-63.

[13] Ansarey M, et al. Optimal energy management in a dualstorage fuel-cell hybrid vehicle using multi-dimensional dynamic programming. J Power Sources 2014;250:359-71.

[14] Odeim F, et al. Power management optimization of an experimental fuel cell/battery/supercapacitor hybrid system. Energies 2015;8:6302-27.

[15] Thounthonga P, et al. Energy management of fuel cell/ battery/supercapacitor hybrid power source for vehicle applications. J Power Sources 2009;193:376-85.

[16] Li Q, et al. Energy management strategy for fuel cell/battery/ ultracapacitor hybrid vehicle based on fuzzy logic. Int J Electr Power Energy Syst 2012;43:514-25.
[17] Amin CJ, et al. Energy management of fuel cell/battery/ supercapacitor hybrid power sources using Model Predictive control. IEEE Trans Industr Inform 2014;10:1192-2002.

[18] Lia T, et al. Hierarchical predictive control-based economic energy management for fuel cell hybrid construction vehicles. Energy 2020;198:117327.

[19] Soumeura MA, et al. Comparative study of energy management strategies for hybrid proton exchange membrane fuel cell four wheel drive electric vehicle. J Power Sources 2020;462:228167.

[20] Lototskyy MV, et al. Performance of electric forklift with lowtemperature polymer exchange membrane fuel cell power module and metal hydride hydrogen storage extension tank. J Power Sources 2016;316:239-50. 